native institutions alone, and not the restricted individual franchise, could attain in India the desired end of government by consent of the whole people.

\section{Metropolitan-Vickers Representatives in Russia}

AT our request, the Metropolitan-Vickers Electrical Co., Ltd., has been good enough to send us the following particulars of its technical representatives, whose recent arrests in Russia have been the subject of a number of questions in Parliament: Mr. Allan Monkhouse, M.I.E.E., A.M.I.Mech.E., who is at present manager in Russia for Metropolitan-Vickers Electrical Export Co., was for several years a senior member of the staff of the Research Department, devoting his interest more particularly during those years to problems on insulation. In addition to his contributions to the scientific press, Mr. Monkhouse wrote "Electrical Insulating Materials" published in 1926. Mr. L. C. Thornton, A.M.I.E.E., Ieft Trafford Park in 1924 to go out to Russia on erection work for Metropolitan-Vickers and has for a number of years been in charge of all erection work in Russia. Mr. J. Cushny, B.Sc.(Eng.), A.M.I.C.E., A.M.I.Mech.E., served his apprenticeship with Metropolitan-Vickers and after serving on the erection staff in Russia for some years, was appointed senior assistant to $\mathrm{Mr}$. Thornton. Messrs. W. L. MacDonald, A. W. Gregory and C. H. de Nordwall, all of whom joined the firm between 1920 and 1922, have been engaged in erection work in Russia for some considerable time. The Metropolitan-Vickers Export Co. has now been supplying plant and machinery to the U.S.S.R. for the last ten years. For the latter part of this time it has had, in addition, an agreement under which technical information and supervision has been supplied by the Company to the U.S.S.R. which has been building the Company's turbines under licence. This agreement is one of the results of the leading position in the field of turbine engineering occupied by the Company, and the agreement has for the last few years been extended to cover the design and manufacture of heavy electrical plant.

\section{Aeronautics and the Royal Air Force}

Sir Philip Sassoon, M.P., Under Secretary of State for Air, in his air estimates speech in Parliament on March 14 offered a good deal of congratulation to the technical and scientific side of the aeronautical community in Great Britain, in that it has managed to maintain progress and extended activities in spite of a progressive reduction in its expenditures. Special tribute was paid to Sir Richard Glazebrook, who retires at the end of this month from the chairmanship of the Aeronautical Research Committee, where he will be succeeded by Mr. H. T. Tizard, rector of the Imperial College of Science and Technology. Sir Richard has been associated with the scientific side of aeronautics since 1909, and has been chairman of the Aeronautical Research Committee since its formation thirteen years ago. Speaking of the Royal Air Force, Sir Philip said that no new squadrons are being formed, although it is still ten short of the 1923 approved programme, and is closing one flying training school. In spite of reductions it has rendered both direct and indirect assistance to the administration of law and order in the more backward of the Empire territories overseas. The suppression of turbulent tribes, transporting of British troops to stiffen up disaffected native levies, giving flights to political agents and local chiefs in areas in which the inhabitants still held that aircraft were a myth, making a flight over the Himalaya range in 2 hours 20 minutes, which normally needed a 17 day march, are among the direct activities mentioned.

THE humanitarian and less directly productive work carried out by the Royal Air Force during the past year is equally striking. Supply of medical services, flood warnings, surveying, fishery protection, locust fighting, famine relief, mail carrying to isolated communities, have absorbed as much as 40 per cent of the flying time of some of the Middle East squadrons. The making of record flights, such as the recent long distance to the Cape, which now brings the records for speed, height, and distance to British aeronautics, is not without its indirect value to Great Britain's prestige. A new system of subdivision of duties amongst R.A.F. mechanics will make considerable saving in the cost of personnel without affecting the technical efficiency of the aircraft maintenance. This is due to the complete change over to all-metal aireraft. Dealing with civil aviation, Sir Philip referred to the continued expansion of Imperial Airways and promised the Indian extension of the Australian air route during 1933. Air passenger traffic has increased by more than 100 per cent on European, and more than 50 per cent on other Empire, routes.

\section{The Panda at the Zoological Gardens}

THe carnivores are really a very remarkable group, ranging in size from the tiger to the weasel, and presenting singular contrasts in the matter of shape. Nor are they all flesh-eaters, some being almost exelusively vegetarians, and one, the kinkajou, has developed a prehensile tongue, like an ant-eater, and a prehensile tail like a spider-monkey. The shape of the body has been moulded by adjustment to their feeding habits. Some have become burrowers, some arboreal, and some aquatic. Their coloration has in like manner been governed by this same factor of food-hunting which of course determines their environment, as witness the polar bear, the tiger, the leopard, and the Cape hunting dog. But there are many other and less familiar types of coloration. Among these is the singular panda (Aelurus fulgens), a recent arrival at the Zoological Gardens, Regent's Park. It is a creature which cannot fail to attract the attention of visitors owing to its striking coloration. A native of the south-eastern Himalayas, where it lives among rocks and trees at a height of $7,000-12,000 \mathrm{ft}$., its habits, and the relation thereto of its coloration, have never been the subject of careful observation. Placed under relatively natural surroundings-which is hecoming more and more a distinctive feature of the Gardens-some useful information may be gleaned on this head. 
As touching the coloration of the panda in relation to its haunts, we have little to build on at the moment, for while some tell us it is found among the rocks, others tell us that it is arboreal. Probably it affects both environments as circumstances may determine. The racoons, to which tribe it belongs, display a similar versatility. The general hue of the upper part of the body is of a lively chestnut-red, with white markings on the face, while the legs and belly are black. The tail, nearly as long as the body, displays the rings characteristic of the racoon. Since it is largely a vegetarian, with a fondness for fruit, this coloration must be regarded as protective : and it may bear some relation to the positions assumed during sleep when protection of this kind is most needed. But here again we are in need of further observation; for it is said to sleep coiled up like a cat with the bushy tail over its head, but at other times resting on its haunches with the head tucked under the chest, and between the fore-legs, after the manner said to be common with the racoons. Here, surely, is a matter which can be settled at the Gardens.

\section{Photoelectric Exhibition at the Science Museum}

A SPECIAL exhibition devoted to photoelectric cells and their practical applications will be opened at the Science Museum, South Kensington, on March 25, and will remain on view for three months. Photoelectric cells are now being widely applied both in pure science and in industry, and the exhibition is intended to give an illustration of the great variety of these applications. Besides exhibits showing the construction of the three main types of light-sensitive cell, some simple working experiments have been arranged to demonstrate their properties and to illustrate some of the methods of amplifying the small currents yielded by the cells under varying illuminations. The practical applications of photoelectric cells can be roughly classified into those involving only the detection of light and those involving its measurement. The first class is illustrated in the exhibition by a number of working models showing the use of the cells, for example, for counting small packages on a conveyor belt, and in burglar alarms, while, as an illustration of the way in which a comparatively large amount of power can be controlled, there is a door which is automatically opened whenever a certain beam of light is interrupted by the visitor. Applications involving the measurement of light intensity are also illustrated. These include the measurement of daylight or of indoor lighting, the automatic switching of street-lamps, and the measurement of the density of factory smoke, while the ability of photoelectric cells to respond to rapidly fluctuating light is shown by their well-known applications in the reproduction of sound from sound-films, and their use in television.

\section{Early American Bridges}

Ax a meeting of the Newcomen Society held at the Caxton Hall, Westminster, on March 15, Capt. L. N. Edwards, of the United States Bureau of Roads, read a paper on "The Evolution of Early American Bridges" in which he dealt with the work of the bridge pioneers of America down to the time of the Civil War of 1861-65. All the early settlements, he said, were situated on sheltered bays, tidal inlets or navigable streams and "the water was the first American highway". When roads came to be constructed, it was natural that the necessary bridges should be simply tree trunks felled at the site. Transportation developments were a challenge to those engaged in bridge building and the art of carpentry became of immense importance. In the eighteenth century, pile and trestle bridges came into use and these were followed by arched and trussed structures, some of great span. The Upper Ferry Bridge over the Schuylkill River built by Louis Wernag in 1812 had a wooden arch of $340 \mathrm{ft}$. span and the McCalls Ferry Bridge over the Susquehana River built by Theodore Burr in 1814 had a central span of $364 \mathrm{ft}$. Especially important were the trusses patented by Ithiel Town, 1820, Col. S. H. Long, 1830, William Howe, 1840 and the two Pratts, 1844. A wrought-iron chain suspension bridge was built by James Finley in 1801, while in 1842 Col. Charles Ellet built the first wire suspension bridge in America. Cast iron was successfully used for a bridge in 1836 . Sixty-seven patents for bridges were issued by the United States Patent Office between 1797 and 1860. The first books on bridge work were by Herman Haupt, 1842, and Squire Whipple, 1847. Capt. Edwards's paper, which was illustrated with many lantern slides, is a notable addition to the history of the subject of American bridges.

\section{Cosmic Radiation}

IN his Symons Memorial Lecture delivered before the Royal Meteorological Society on March 15, Mr. P. M. S. Blackett dealt with "Cosmic Radiation". The study of what is now known as cosmic or penetrating radiation began more than thirty years ago with the experimental investigation of the conductivity of the air in closed vessels. By 1932, measurements of the ionisation had been carried out up to heights of $28 \mathrm{~km}$. in the atmosphere and down to depths of $230 \mathrm{~m}$. under water. The ionisation is found to be 100,000 times more intense at the highest point reached compared with that at the greatest depth. More than four hundred papers have been written on the subject and still the nature of the primary radiation is not certain and its origin quite unknown. The ionisation is constant in time to within two per cent at any one place, but is about twelve per cent less intense at the equator than in latitudes of $50^{\circ} \mathrm{N}$. and $\mathrm{S}$. From these latitudes to the poles it is nearly constant. It is probable, but not certain, that the primary radiation incident on the earth's atmosphere consists of an isotropic corpuscular radiation with a mean energy of more than $10^{10}$ volts. The actual ionisation at sea level is due to fast particles, mainly electrons, protons and 'positive electrons'. The tracks of these particles can be photographed by the cloud method and such photographs have shown that very complex phenomena of great variety and interest oceur in connexion with the absorption of the primary cosmic rays by matter. 